\title{
In Vitro Study of the Effects of Fluoride-Releasing Dental Materials on Re-Mineralization of Deciduous Teeth
}

\author{
Damyanova Dobrinka $\mathrm{M}^{1}$ \\ ${ }^{1}$ Assistant Professor, Medical University-Varna, Bulgaria, Faculty of Dental Medicine, \\ Department of Pediatric Dental Medicine
}

\begin{abstract}
Purpose: This study has been conducted to compare the re-mineralization effects of five regimens of fluoride varnishes and pastes on the loss of fluorescence intensity, in vitro model-deciduous teeth.

Methods: Forty deciduous intact teeth enamel surfaces were etched for 60 sec. Teeth surfaces were prepared into the five following groups which were treated with dental materials: (1) Fluor Protector (FP), (2) Clinpro White Varnish (CV), (3) Gum paste 500 ppm F, (4) Gum paste 1000 ppm, (5) Tooth Mousse (TM). Only CV is intended to be applied on dentin surfaces. They were investigated using DIAGNOdent Pen to measure the values of laser fluorescence of intact enamel surfaces.

Results: Results in enamel structure were decreased with two degrees in the all models. Results in dentin structure after application with $C V$ were decreased with 1.30 degree. We have not established any significant variations of the values after application of CV,TM and GUM paste 1000 ppm on intact enamel surfaces.

Conclusions: Clinpro white varnish $(\mathrm{CV})$ dental materials can promote greater effect of re-mineralization of the artificially provoked enamel lesions than can F-based dental materials do.

Keywords: DIAGNOdent Pen, demineralization, re-mineralization, laser fluorescence, deciduous teeth.
\end{abstract}

\section{Introduction}

The enamel non-cavitated lesions of human teeth can be caused by caries, tooth wear and congenital dental anomalies, all of them resulting on the irreversible loss of dental hard tissues [1-3]. The primary mineral in enamel is hydroxyapatite, which is a crystalline calcium phosphate into calcium phosphate and hydroxyl ions [4,5]. The usefulness of fluoride-releasing materials for enamel re-mineralization has been demonstrated in various models, using different methods [6,7,10,11]. Enamel re-mineralization has been studied for approximately 100 years, during which time many successful re-mineralizing agents have been made available $[8,9,12]$. The re-mineralization efficiency of fluoride-releasing dental materials is related to the fluoride content, fluoride matrices, setting mechanisms and other material components $[13,14,15,16]$. Contemporary approaches to the treatment of enamel lesions are based on the idea of "demineralization and re-mineralization" in a microphase to retain healthy teeth [17].

\section{Materials and methods}

This study included all groups of 40 deciduous teeth. All used teeth are deciduous and have fallen by physiological change break-through from permanent. All teeth have complete root resorption, all teeth are with open pulp chamber-senile period of deciduous teeth. The teeth were cleaned to remove all soft and hard tissues prior to testing. DIAGNOdent Pen with a probe for occlusive pit-and-fissure tooth decay and smooth surface was used.

The study was performed in the following sequence:

1. DIAGNOdent pen was calibrated with intact enamel surface standard before starting the measurements and after testing.

2. The values on intact enamel and dentin surfaces were measured.

3. The samples were treated with $37 \% \mathrm{H}_{2} \mathrm{PO}_{3}$ etchant, in order to induce a stimulated process of demineralization, as follows:

a. 40 enamel surfaces were etched for $60 \mathrm{sec}$.

b. Teeth were rinsed, dried and measured again with DIAGNOdent Pen.

4. Re-mineralization

Forty teeth surfaces were prepared and divided into five groups, which were treated with the following dental materials: (1) Fluor Protector(FP) with 0,1\% concentration of fluoride components, (2) Clinpro White Varnish (CV)Tri-Calcium Phosphate containing 22,6mg F, (3) Gum kids paste with 500ppm F, (4) Gum paste with 1000ppm, (5)Tooth Mousse (CPP-ACP cannot compare with that of fluoride agents). The enamel of the 
three windows was re-mineralized (1,2,3,4,5- dental materials) for 1 hours, at $37^{\circ} \mathrm{C}$ - air temperature in the stacked plastic bags.

Only Clinpro White Varnish is intended to be applied on dentin surfaces and used as a cement-based filling material, since only it is recommended for this purpose. After the procedure of re-mineralization, the specimens of each group were divided into five groups and tested by the method applying DIAGNOdent Pen.

\section{Results \\ The results obtained from the study are presented on Tables 1 and 2.}

After application of Clinpro White Varnish on the enamel surfaces for one hours an average decrease of $6,15( \pm 2,03)$ was detected. After application of Fluor Protector on the enamel surfaces for one hours an average decrease of $6,37( \pm 3,05)$ of the indicator of fluorescence intensity was detected. After applications of GUM paste with $\mathrm{F}$ concentration of $500 \mathrm{ppm}$ and $1000 \mathrm{ppm}$ upon the enamel surfaces for one hours an average decrease of $5,85( \pm 2,27)$ and $4,83( \pm 1,46)$, respectively, was detected. The detected average values of decrease of laser fluorescence of the enamel were 4,37 $( \pm 1,35)$ - for GUM paste with $500 \mathrm{ppm} \mathrm{F}$ and 4,67 $( \pm 1,54)$ for GUM paste with 1000 ppm F, respectively.

Results in enamel structure were decreased with two degrees in the models with all dental materials after demineralization, an average increase 9,40 $( \pm 3,27)$ and after re-mineralization- an average decrease of $5,58( \pm 2,04)$. Average decrease for FP and GUM paste $500 \mathrm{ppm}$ were $6,37( \pm 3,05)$ and $5,85( \pm 2,27)$ in comparison an average value for intact enamel surfaces $3,85( \pm 1,29)$ and $4,37( \pm 1,35)$. We did not observe any significant variations of the values after application of CV,TM and GUM paste $1000 \mathrm{ppm}$ on enamel surfaces.

The results of the comparative analysis of the therapeutic effectiveness of used dental varnishes Fluorine Protector and Clinpro White Varnish showed a significant difference in the percentage of efficiency ( $\mathrm{t}$ $=-3,68, \mathrm{p}<0.001)$, as Clinpro White Varnish shows better results after application $(64,58 \%)($ Table 1). The study of the accompanying GUM toothpastes also showed a significant difference in performance $(\mathrm{t}=2,60$, $\mathrm{p}=0.011)$, as GUM kids paste -500 ppm showed better results $(67,89 \%)$ compared with the paste GUM - 1000 ppm $(58,72 \%)$ (Table 1$)$.

Research and pastes showed a significant difference in terms of reduction of avtofluorestsentsiyata after application $(\mathrm{t}=2,39, \mathrm{p}=0.02)$, as GUM kids pasta $-1000 \mathrm{ppm}$ indicated better results 4.83 to 5.85 , for

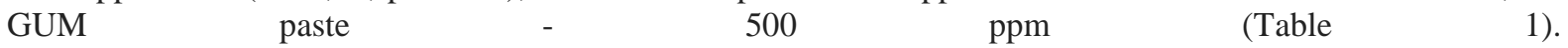
Analysis of therapeutic effectiveness in all the dental means shows that the results obtained after application of Tooth Mousse superior to those of the other vehicles $(\mathrm{F}=9,49, \mathrm{p}<0.001)$. Clinpro White Varnish is third in effectiveness after Tooth Mousse and GUM kids pasta - 500 ppm. (Table 1).

The results in Table 2 show that univariate regression analysis achieves higher values of the coefficient in the lacquer Fluor protector $(\beta=0,598)$ with respect to the study of the relationship between the effectiveness and the reduction of fluorescence, this dental varnish influences $34,10 \%$ of the changes achieved in therapeutic efficacy, and the lowest dependence was observed in Clinpro White Varnish $(\beta=0,332)$, which affects only $8.70 \%$ of variations in performance.

\section{Discussion}

The enamel in vitro lesions values for $\mathrm{d} 1-7$ to 12 . Clinpro white varnish (CV) dental materials can promote greater effect of re-mineralization of the artificially provoked enamel lesions than can F- based dental materials do. Our results showed that $\mathrm{CV}$ was more effective than FP in the process of re-mineralization of teeth surfaces. Moreover, CV also contains calcium and phosphate ingredients, which are necessary and serve as useful supplements in the process of re-mineralization. Based on the results of the four methods of investigation, we found that TM did not have significant properties of re-mineralizing effect, compared with the fluoridereleasing dental materials. The loss of fluorescence intensity of FP, CV, GUM paste 500 ppm, GUM paste $1000 \mathrm{ppm}$ group showed significant reduction after the procedure of re-mineralization. We hope that these results can serve as scientifically-established prerequisite for the clinical application of these materials.

\section{Conclusions}

1. According to this in vitro conducted study may be concluded that changes in the degree of remineralization of deciduous teeth structures can be detected by using DIAGNOdent Pen.

2. The procedure of enamel etching for $60 \mathrm{sec}$. provides conditions for comparison of variations of the degree of laser fluorescence.

3. The obtained values after $60 \mathrm{sec}$. of etching revealed an almost double increase compared with the average value for intact enamel surfaces.

4. The obtained values after a time interval of one hours of applications revealed an almost double decrease of fluorescence intensity compared to the procedure of etching for $60 \mathrm{sec}$. of the enamel layer. 
5. Clinpro white varnish $(\mathrm{CV})$ dental materials can promote greater effect of re-mineralization of the artificially provoked enamel lesions than can F-based dental materials do.

\section{References}

[1]. Ranjitkar S, Rodriguez JM, Kaidonis JA, Richards LC, Townsend GC, Bartlett DW. The effect of casein phosphopeptideamorphous calcium phosphate on erosive enamel and dentine wear by toothbrush abrasion. Journal of Dentistry 2009;37:250-4.

[2]. Rees J, Loyn T, Chadwick B. Pronamel and tooth mousse:an initial assessment of erosion prevention in vitro. Journal of Dentistry 2007;35:355-7.

[3]. Crombie F, Manton D, Kilpatrick N. Aetiology of molar-incisor hypomineralization:a critical review.International Journal of Paediatric Dentistry 2009;19:73-83.

[4]. Peneva M, Rashkova M, Doychinova L. Age distribution of caries lesions in children"s permanent teeth-a basis for the choice of a therapeutic solution.,Journal of IMAB-Annual Proceeding(Scientific Papers),13,2007 ,book 2,57-59/Published online-Dec.12, 2007www.journal-imab-bg.org/;

[5]. Rashkova M, Peneva M, Doychinova L.Study of the risk factors for the development of dental caries and creation of a system for evaluation of the risk of caries in children.-OHDMBSC,7,2008,2, pp. 3-11.

[6]. Burke FM, Ray NJ, Mc Connell RJ. Fluoride-containing restorative materials. International Dental Journal. 2006;56:33-43.

[7]. Rodrigues E, Delbem AC, Pedrini D, de Oliveira MS. PH-cycling model to verify the efficacy of fluoride-releasing materials in enamel demineralization. Operative Dentistry. 2008;33:658-65.

[8]. Robinson C, Connell S, Kirkham J, Brookes SJ, Shore RC, Smith AM. The effect of fluoride on the developing tooth. Caries Research. 2004;38:268-76.

[9]. Robinson C. Fluoride and the caries lesion: interactions and mechanism of action. European Archives of Paediatric Dentistry. 2009;10:136-40

[10]. Ikemura K, Tay FR, Endo T, Pashley DH. A review of chemical-approach and ultramorphological studies on the development of fluoride-releasing dental adhesives comprising new pre-reacted glass ionomer (PRG) fillers. Dental Materials Journal. 2008;27:31539.

[11]. Okuyama K, Murata Y, Pereira PN, Miguez PA, Komatsu H, Sano H. Fluoride release and uptake by various dental materials after fluoride application. American Journal of Dentistry. 2006;19:123-7.

[12]. ten Cate JM. Current concepts on the theories of the mechanism of action of fluoride. Acta Odontologica Scandinavica. 1999;57:325-9.

[13]. Murdoch-Kinch CA, McLean ME. Minimally invasive dentistry. Journal of the American Dental Association. 2003;134:87-95.

[14]. Malterud MI. Minimally invasive restorative dentistry:a biomimetic approach. Practical Procedures \& Aesthetic Dentistry. 2006;18:409-14

[15]. Lee YE, Baek HJ, Choi YH, Jeong SH, Park YD, Song KB. Comparison of remineralization effect of three topic fluoride regimens on enamel initial carious lesions. Journal of Dentistry. 2010;38:166-71.

[16]. Lata S, Varghese NO, Varughese JM. Remineralization potential of fluoride and amorphous calcium phosphate-casein phosphor peptide on enamel lesions:an in vitro comparative evaluation. Journal of Conservative Dentistry. 2010;13:42-6.

[17]. Ahiropoulos V, Helvatjoglu-Antoniades M, Papadogiannis Y. In vitro fluoride uptake by bovine enamel from aesthetic restorative materials.International Journal of Paediatric Dentistry. 2008;18:291-9.

Address for correspondence:

D-r Dobrinka Damyanova

Department of Pediatric Dental Medicine Faculty of Dental Medicine, Medical University-Varna, Bulgaria 84, Tzar Osvoboditel, 9000 Varna, Bulgaria E-mail: dr_damyanova@abv.bg

Table 1. Changes in laser fluorescent measurements detected for enamel after applicaton with dental materials

\begin{tabular}{|l|l|l|l|l|l|}
\hline $\begin{array}{l}\text { Dental } \\
\text { materials }\end{array}$ & $\begin{array}{l}\text { Fluor } \\
\text { Protector } \\
\text { Performance }\end{array}$ & $\begin{array}{l}\text { Clinpro } \\
\text { White } \\
\text { Varnish }\end{array}$ & $\begin{array}{l}\text { GUM kids } \\
\text { paste-500ppm }\end{array}$ & $\begin{array}{l}\text { GUM kaste } \\
\text { 1000ppm }\end{array}$ & $\begin{array}{l}\text { Tooth } \\
\text { Mousse }\end{array}$ \\
\hline $\begin{array}{l}\text { Number of } \\
\text { surfaces }\end{array}$ & 40 & 40 & 40 & 40 & 40 \\
\hline $\begin{array}{l}\text { An average value } \\
\text { for Intact } \\
\text { Enamel surfaces }\end{array}$ & $3,85 \pm 1,29$ & $4,43 \pm 1,01$ & $4,37 \pm 1,35$ & $4,67 \pm 1,54$ & $4,03 \pm 1,31$ \\
\hline $\begin{array}{l}\text { Number of } \\
\text { Surf. With } \\
\text { Decreased } \\
\text { values }\end{array}$ & $0 / 0,0 \%$ & $0 / 0,0 \%$ & $0 / 0,0 \%$ & $0 / 0,0 \%$ & $2 / 5,0 \%$ \\
\hline $\begin{array}{l}\text { An average } \\
\text { Increase } \\
\text { Etching time-60 } \\
\text { sec. }\end{array}$ & $13,00 \pm 4,71$ & $10,00 \pm 3,94$ & $8,57 \pm 2,48$ & $8,47 \pm 2,67$ & $6,97 \pm 2,53$ \\
\hline $\begin{array}{l}\text { An average } \\
\text { Decrease }\end{array}$ & $6,37 \pm 3,05$ & $6,15 \pm 2,03$ & $5,85 \pm 2,27$ & $4,83 \pm 1,46$ & $4,72 \pm 1,39$ \\
\hline Efficiency in $\%$ & $\begin{array}{l}50,45 \\
(7,60\end{array}$ & $64,58 \pm 16,71$ & $67,89 \pm 15,26$ & $58,72 \pm 16,29$ & $70,36 \pm 15,94$ \\
\hline
\end{tabular}


Tabl. 2. Correlation between the effectiveness and the decrease in fluorescence at different types of dental tools

\begin{tabular}{|l|l|l|l|l|}
\hline Dental medications & $\begin{array}{l}\text { Nonstandard } \\
\text { Factor } \square\end{array}$ & Standard Factor $\square$ & $\mathbf{p}$ & $\begin{array}{l}\text { Adjusted } \\
\mathbf{R}^{\mathbf{2}}\end{array}$ \\
\hline $\begin{array}{l}\text { Fluor } \\
\text { Protector }\end{array}$ & 0,104 & 0,598 & $<0,001$ & 0,341 \\
\hline $\begin{array}{l}\text { Clinpro White } \\
\text { Varnish }\end{array}$ & 0,040 & 0,332 & 0,036 & 0,087 \\
\hline GUM kids paste-500ppm & 0,089 & 0,601 & $<0,001$ & 0,344 \\
\hline $\begin{array}{l}\text { GUM kids paste- } \\
\text { 1000ppm }\end{array}$ & 0,039 & 0,436 & 0,005 & 0,168 \\
\hline Tooth Mousse & 4,342 & 0,380 & 0,016 & 0,122 \\
\hline
\end{tabular}

